\title{
Acute choke zone effects: Lessons from radioactive and fluorescent microspheres in a pig model muscle flap
}

\author{
DJ Courtemanche MD MS FRCSC 1,2 , WG Cannon BSc ${ }^{3}$, RJM Courtemanche $\mathrm{MSc}^{4}$, \\ JS Williamson MD FRCSC ${ }^{5}$, D Lyster $\mathrm{PhD}^{6}$
}

DJ Courtemanche, WG Cannon, RJM Courtemanche, JS Williamson, D Lyster. Acute choke zone effects: Lessons from radioactive and fluorescent microspheres in a pig model muscle flap. Plast Surg 2015;23(3):171-176.

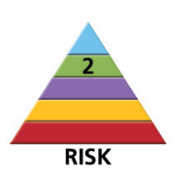

BACKGROUND: Choke vessels dilate and contract to regulate blood flow between adjacent arterial angiosomes. In skin flap surgery, when arterial inflow to an angiosome is ligated, choke vessels allow blood supply from an adjacent angiosome. In muscle flap surgery, the vascular anatomy is analogous to skin flaps; however, while it is established that the choke vessels will fully dilate irreversibly after two to three days, no study has yet analyzed the acute changes in each vascular region immediately following ligation of one pedicle.

OBJECTIVE: To establish whether the choke vessels open or close immediately following ligation of a pedicle, and how this change affects blood flow in the adjacent proximal and distal vascular regions.

METHODS: Radioactive and fluorescent microspheres in a pig model were used to study the regional intramuscular blood flow in each anatomical zone of a rectus abdominis flap. Blood flow measurements for each zone were calculated relative to the entire muscle at preligation, ligation and various times (15 $\mathrm{min}$ to $90 \mathrm{~min}$ ) postligation.

RESULTS: There was no statistically significant difference in blood flow across choke zones as a result of ligation. This signifies that the choke vessels do not significantly dilate to produce a statistically significant measureable change in blood flow.

CONCLUSIONS: Given these results and previous literature findings, the anatomical presence of choke vessels in a muscle is the strongest determining factor for acute flap viability in surgery.

Key Words: Blood flow; Choke zone; Fluorescent microspheres; Pig model; Radioactive microspheres; Rectus abdominis flap

Plastic surgeons are being called on to deal with increasingly complex wounds and deformities from trauma, burns, cancer and birth defects. The muscle flap is a valuable technique for closing wounds too extensive to permit primary closure by suturing and/or too poorly vascularized to permit a skin graft (1). Free muscle transfers for treatment of large, complex, poorly vascularized wounds are considered to be a salvage procedure and often result in significant morbidity. As knowledge of the physiology of muscle flaps develops, the ability to define indications and predict outcomes for this technique improves.

Blood flow is one of the main factors in determining the viability of flaps (2). Muscle flap surgery is, therefore, dependent on the precise knowledge of vascular anatomy. Mathes and Nahai (3) have classified muscle vascular anatomy based on pedicle arrangement, in which a muscle may contain several vascular territories. Each territory is supplied by at least one vascular pedicle. During muscle flap surgery, the muscle must be isolated onto one, usually the dominant, vascular pedicle. Consequently, the interconnecting choke vessels (microscopic
Les effets des zones anastomotiques aiguës : leçons tirées de microsphères radioactives et fluorescentes dans un lambeau musculaire de porc

HISTORIQUE : Les vaisseaux anastomotiques se dilatent et se contractent pour réguler le débit sanguin entre les angiosomes artériels adjacents. Dans le cadre d'une chirurgie par lambeau cutané, lors de la ligature du débit artériel vers un angiosome, les vaisseaux anastomotiques assurent un débit sanguin en provenance d'un angiosome adjacent. L'anatomie vasculaire est alors analogue aux lambeaux cutanés. Cependant, bien qu'il soit établi que les vaisseaux anastomotiques se dilatent pleinement et de manière irréversible au bout de deux ou trois jours, aucune étude n'a encore analysé les changements aigus de chaque région vasculaire immédiatement après la ligature d'un pédicule.

OBJECTIF : Établir si les vaisseaux anastomotiques s'ouvrent ou se ferment immédiatement après la ligature d'un pédicule et examiner l'effet de ce changement sur le débit sanguin des régions proximales et distales adjacentes. MÉTHODOLOGIE : Les chercheurs ont utilisé les microsphères radioactives et fluorescentes d'un porc pour étudier le débit sanguin intramusculaire régional de chaque zone anatomique d'un lambeau du grand droit. Ils ont mesuré le débit sanguin de chaque zone par rapport au muscle entier avant la ligature, au moment de la ligature et à divers moments (de 15 à 90 minutes) après la ligature.

RÉSULTATS : Il n'y avait pas de différence statistiquement significative du débit sanguin dans les diverses zones anastomotiques après une ligature. Ainsi, les vaisseaux anastomotiques ne se dilatent pas au point de produire un changement du débit sanguin pouvant être mesuré de manière statistiquement significative.

CONCLUSIONS : Compte tenu de ces résultats et des conclusions de publications scientifiques, la présence anatomique de vaisseaux anastomotiques dans un muscle est le principal déterminant de viabilité aiguë d'un lambeau lors d'une chirurgie.

\footnotetext{
${ }^{1}$ University of British Columbia; ${ }^{2}$ Department of Surgery, British Columbia Children's Hospital; ${ }^{3}$ Division of Plastic Surgery, University of British Columbia; ${ }^{4}$ British Columbia Children's Hospital, Vancouver; ${ }^{5}$ Department of Surgery, Kelowna General Hospital, Kelowna, ${ }^{6}$ Department of Radiology, Vancouver Hospital $\mathcal{E}$ Health Sciences Centre, Vancouver, British Columbia

Correspondence: Dr Douglas J Courtemanche, British Columbia Children's Hospital, K3-131 ACB, 4480 Oak Street, Vancouver,

British Columbia V6H 3V4. Telephone 604-875-2291, fax 604-875-2749, e-mail douglas.courtemanche@ubc.ca
} 
TABLE 1

Microspheres used at each time point

\begin{tabular}{lccccc}
\hline & \multicolumn{5}{c}{ Time } \\
\cline { 2 - 6 } Experiment & Baseline & Ligation (0 min) & $\mathbf{1 5} \mathbf{~ m i n}$ & $\mathbf{6 0} \mathbf{~ m i n}$ & $\mathbf{9 0} \mathbf{~ m i n}$ \\
\hline 1 & ${ }^{153} \mathrm{Gd}$ & ${ }^{57} \mathrm{Co}$ & ${ }^{113} \mathrm{Sn}$ & - & - \\
2 & ${ }^{153} \mathrm{Gd}$ & ${ }^{57} \mathrm{Co}$ & ${ }^{113} \mathrm{Sn}$ & - & - \\
3 & $\mathrm{OR}$ & $\mathrm{YG}$ & $\mathrm{CR}$ & - & - \\
4 & $\mathrm{YG}$ & $\mathrm{OR}$ & $\mathrm{CR}$ & $\mathrm{RD}$ & - \\
5 & $\mathrm{RD}$ & $\mathrm{CR}$ & - & $\mathrm{YG}$ & $\mathrm{CR}$ \\
\hline
\end{tabular}

Radioactive microspheres: ${ }^{57}$ Co Cobalt-57 (half life [t $\left.{ }_{1 / 2}\right] 271.7$ days); ${ }^{153} \mathrm{Gd}$ Gadolinium-153 ( $t_{1 / 2} 242.0$ days); ${ }^{113} \mathrm{Sn}$ Tin-113 ( $t_{1 / 2} 115.1$ days). Fluorescent microspheres: CR Crimson; OR Orange; RD Red; YG Yellow-green

A study from our laboratory using swine bipedical rectus abdominis muscle flaps showed that surgical excision of choke vessels did not result in a significant drop in vascular resistance per unit weight (7). The conclusions were that vascular resistance was found to increase as flaps were serially resected; the myogenic response may control blood flow in muscle flaps; and the role of choke vessels in muscle flap failure remained unclear $(1,7)$.

In 2001, a clinical study of vascular resistance in muscle flaps showed that larger muscles have less vascular resistance $(2,8)$. The implication of this was that larger flaps, with fewer choke vessels, should be used when high flow is critical. The lower resistance associated with increased flap size resulted in improved vein graft patency $(3,8)$. Kurita et al $(9)$ measured alterations in arterial blood flow following free muscle transfer by studying a vascularized latissimus dorsi muscle segment for the reconstruction of a paralyzed face $(4,9)$. They concluded that preoperative arterial blood flow and volume of transferred tissue (weight) correlated with postoperative blood flow and was crucial to free flap transfer and vascular patency $(5,9)$. Moreover, the duration of ischemia was not influential in free flap transfers $(6,9)$. These results suggest that the amount of choke vessels giving rise to an initial vascular resistance plays more of a role in muscle flap viability than pausing for the choke vessels to theoretically open before muscle flap transfer. In agreement with this trend, a recent comprehensive analysis of the risk factors associated with free flap loss in breast reconstruction found a correlation between higher losses and longer ischemia times $(7,10)$.

While previous literature has indicated that vascular resistance is the most important factor in determining muscle flap viability and delaying transfer to allow for dilation of choke vessels is inconsequential, a full analysis of the blood flow patterns during the time muscle flap surgery has yet to be elucidated. Our research goal is to establish the acute role of the choke zone in a muscle flap, ie, whether the choke zone vessels dilate in response to ligation, and how the changes in blood flow from one anatomical region affect blood flow in adjacent anatomical regions. Toward this goal, we therefore aimed to study blood flow patterns in a rectus abdominis muscle in a pig model using radioactive and fluorescent microsphere protocols. The physiological knowledge gained from our study will advance current understanding of the choke zone in muscle flap surgery.

\section{METHODS}

Changes in the regional intramuscular blood flow in three anatomical zones: distal, choke and proximal, were analyzed following ligation of the deep inferior epigastric artery of a swine rectus abdominis flap. The rectus abdominis muscle flap was chosen because this muscle was previously found to have the lowest vascular resistance. The rectus abdominis muscle is defined as having a type III vascular pattern with two vascular pedicles arising from separate regional arteries (1). The pig model was selected because they are commonly used for flap experimentation and have a well-understood anatomy (11). As in the human, the swine rectus abdominis muscle flap consists of two territories supplied by a distal pedicle - the deep inferior epigastric artery (DIEA), and the proximal pedicle - the superior epigastric artery (12). The choke zone lies between the vascular territories of the two arteries within the muscle.
Radioactive and fluorescent techniques have been described by Heymann et al (13) and Tan et al (14), respectively. Hjortdal et al (15) used radioactive microspheres to successfully study the circulation in myocutaneous flaps in a pig model. In a comparison of radioactive and fluorescent microspheres to measure myocardial blood flow in rabbits, Chien et al (16) concluded that both yielded comparable results. The radioactive and fluorescent microsphere procedures used in the following experiments were adapted from Rurak et al (17) and the suppliers' protocols (18).

\section{Animals}

Five Landrace/white cross female pigs (20 kg to $30 \mathrm{~kg}$ ) were used for the present experiment. All had previously been used for another surgical experiment. Care, storage and disposal of the animals adhered to the guidelines of the Canadian Council on Animal Care. Surgery was performed at the Jack Bell Research Centre, Vancouver, British Columbia. The present research study was approved by the University of British Columbia Animal Care Committee (A95-0228).

\section{Radioactive and fluorescent microspheres}

NEN-TRAC radioactive microspheres were purchased from Dupont (USA): gadolinium-153, cobalt-57 and tin-113, with half-lives of 242.0 days, 271.1 days and 115.1 days, respectively. Exposure to radiation, disposal and prolonged storage of radioisotopic carcasses warranted a change to fluorescent microspheres. Four fluorescent microspheres were purchased from Molecular Probes Inc (USA): FluoSpheres (excitation/emission wavelengths): crimson (625/645 nm); orange (540/560 nm); yellow-green, $(505 / 515 \mathrm{~nm})$; and red $(580 / 605 \mathrm{~nm})$. Stock solutions of the radioactive and fluorescent microspheres were prepared, shaken and placed in a sonicating water bath for $30 \mathrm{~min}$ before injection.

\section{Experimental protocol}

The pigs were anesthetized and prepared for surgery. Cardiopulmonary hemodynamics and core temperature stability were ensured with continuous monitoring of heart rate, arterial pressures and repeated measurements of blood gases. A limited left fourth intercostal space thoracotomy was performed to enable placement of a polyethylene catheter for direct injection of either radioactive or fluorescent microspheres into the left atrium, and the carotid artery was cannulated for collection of arterial reference blood samples.

Experimental and control muscle flap preparation: Both the right and left rectus abdominis muscle flaps were elevated on the distal and proximal vascular pedicles with dissection of the DIEA and vein(s) for adequate exposure. The right flap served as the experimental flap, and the left as the control flap.

For each experiment, the microspheres were injected at the time points of interest: baseline blood flow (preligation), blood flow at ligation, and blood flow at various time points postligation $(15 \mathrm{~min}$, $60 \mathrm{~min}$ and $90 \mathrm{~min}$ ) (Table 1). For each time point, three data points were collected: a reference blood flow from the carotid artery; blood flow for the ligated experimental muscle; and blood flow from the nonligated control muscle.

Radioactive microspheres were used for experiments 1 and 2, while fluorescent microspheres were used for experiments 3,4 and 5 (Table 1). The blood flow measurements were extrapolated from the amount of radioactivity or fluorescence microspheres in the tissue. Higher radioactivity or fluorescence corresponded with higher blood flow in the tissue.

Radioactive and fluorescent measurements: Radioactivity or fluorescence was determined following excision of the control and experimental flaps in their entirety. The proximal, choke and distal zones were defined by observation, measured, and sectioned transversely and longitudinally (Figure 1). Radioactivity was measured using a gamma counter (Packard Cobra II Model, Perkin Elmer USA). Control standardization gamma counts for each radioisotope allowed the generation of a mathematical relationship between concentration of an isotope and gamma counts. The concentration of each isotope for every sample was then determined. For the fluorescent microsphere 


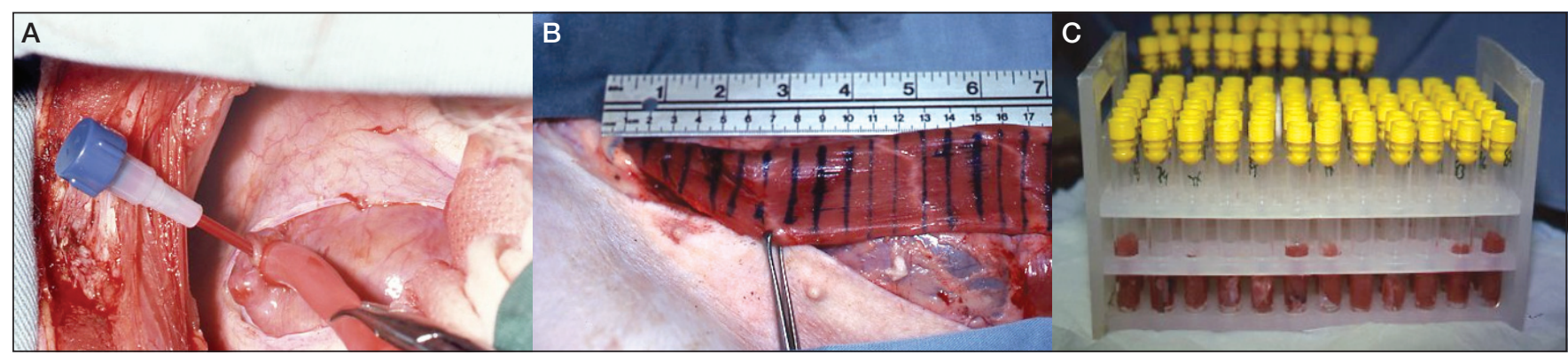

Figure 1) A Polyethylene catheter; B Sectioning of tissue samples; C Tissue samples in tubes

TABLE 2

$t$ test for relative blood flow at different time points over time in the distal, choke and proximal regions of the flaps $(\alpha=0.05)$

\begin{tabular}{|c|c|c|c|c|c|c|}
\hline \multirow[b]{2}{*}{ Time points } & \multicolumn{2}{|c|}{ Distal } & \multicolumn{2}{|c|}{ Choke } & \multicolumn{2}{|c|}{ Proximal } \\
\hline & Experimental & Control & Experimental & Control & Experimental & Control \\
\hline Baseline versus ligation (0 min) & $0.004^{*}$ & 0.410 & 0.233 & 0.975 & $0.005^{*}$ & 0.578 \\
\hline Baseline versus $15 \mathrm{~min}$ & 0.123 & 0.902 & 0.307 & 0.282 & 0.141 & 0.589 \\
\hline Baseline versus $60 \mathrm{~min}$ & $0.077^{*}$ & 0.672 & 0.160 & 0.693 & $0.025^{\star}$ & 0.576 \\
\hline Ligation (0 min) versus $15 \mathrm{~min}$ & 0.523 & 0.967 & 0.128 & 0.839 & 0.187 & 0.985 \\
\hline Ligation (0 min) versus $60 \mathrm{~min}$ & 0.487 & 0.697 & 0.254 & 0.482 & 0.792 & 0.946 \\
\hline $15 \mathrm{~min}$ versus $60 \mathrm{~min}$ & 0.916 & 0.700 & 0.097 & 0.612 & 0.389 & 0.928 \\
\hline
\end{tabular}

${ }^{*} P<0.05$

experiments, the microspheres were first extracted from the tissue using a sedimentation method before analysis by fluorimetry (18).

Data analysis: Radioactive measurements were corrected for background and decay rates, while fluorescent measurements were corrected for background and spillover amounts. The reference blood flow withdrawal rate of $10 \mathrm{~mL} / \mathrm{min}$ was used to calculate the blood flow in all tissue samples according to Equation 1 and Equation 2.

$$
\underset{\left(\mathrm{mLmin}^{-1}\right)}{\text { Blood Flow }}=\underset{\text { Withdrawal Rate }}{\text { Weference Blood }} \times \frac{\mathrm{I}_{\text {tissue }}}{\mathrm{I}_{\text {reference }}}=10 \mathrm{mLmin}^{-1} \times \frac{\mathrm{I}_{\text {tissue }}}{\mathrm{I}_{\text {reference }}}
$$

Equation 1. Calculation of blood flow rate $(\mathrm{mL} / \mathrm{min}) ; \mathrm{I}=$ radioactive counts or fluorescence intensity (18).

$$
\text { Blood Flow }\left(\mathrm{mLmin}^{-1} \mathrm{~g}^{-1}\right)=\frac{\text { Blood flow }\left(\mathrm{mLmin}^{-1}\right)}{\text { Mass of tissue }(\mathrm{g})}
$$

Equation 2. Blood flow per gram (g) of tissue

Each tissue section was measured in triplicate and from this an average blood flow was calculated. The average blood flow for each anatomical zone (proximal, choke and distal) was then calculated for and normalized against the whole muscle blood flow at the same time point, Equation 3. After normalization, the data for all five experiments could be combined to obtain an average blood flow for each anatomical region over time. Statistical analysis of the blood flow rate at each time point as well as analysis between the experimental and control muscle blood flow rates were performed at the $95 \% \mathrm{CI}$ $(\alpha=0.05)$ using the Student's $t$ test.

$$
\text { Blood Flow }=\frac{\text { Blood flow in anatomic zone at } \mathrm{t}_{\mathrm{i}}\left(\mathrm{mLmin}^{-1} \mathrm{~g}^{-1}\right)}{\text { Blood flow in whole muscle at } \mathrm{t}_{\mathrm{i}}\left(\mathrm{mLmin}^{-1} \mathrm{~g}^{-1}\right)}
$$

Equation 3. Normalized blood flow rate; $t_{i}=$ time (min)

Method validation: To validate the fluorescent microsphere extraction procedure, various sample spikes were prepared using the muscle tissue or blood matrices and a known amount of fluorescent microspheres. Using a standard calibration curve, the percent recovery of each spike was calculated, indicating how each sample matrix influenced fluorescent intensity.

\section{RESULTS}

The normalized blood flow rates were obtained from all five experiments and averaged for each anatomical region (distal, choke and proximal) for the experimental and control muscle at each time point.

At baseline (preligation), the blood flow in the experimental muscle for the distal, choke and proximal regions were $1.16 \pm 0.54 \mathrm{~mL} / \mathrm{min}$, $0.89 \pm 0.17 \mathrm{~mL} / \mathrm{min}$ and $1.04 \pm 0.13 \mathrm{~mL} / \mathrm{min}$, respectively. These rates were similar to the blood flow in the control muscle: $1.12 \pm 0.55 \mathrm{~mL} / \mathrm{min}$ $(\mathrm{P}=0.8888), 1.07 \pm 0.31 \mathrm{~mL} / \mathrm{min}(\mathrm{P}=0.0417)$ and $0.90 \pm 0.28 \mathrm{~mL} / \mathrm{min}$ $(\mathrm{P}=0.1856)$ for the distal, choke and proximal regions, respectively.

At the time of ligation, a sharp decrease in the blood flow was observed in the experimental muscle, with the least blood flow in the distal region: $0.49 \pm 0.16 \mathrm{~mL} / \mathrm{min}, 0.80 \pm 0.09 \mathrm{~mL} / \mathrm{min}$ and $1.33 \pm 0.05$ $\mathrm{mL} / \mathrm{min}$ for the distal, choke and proximal regions, respectively. These rates all had a statistically significant difference to the blood flow in the control muscle at the same time: $1.19 \pm 0.57 \mathrm{~mL} / \mathrm{min}(\mathrm{P}=0.0273)$, $1.07 \pm 0.15 \mathrm{~mL} / \mathrm{min}(\mathrm{P}=0.0021)$ and $0.87 \pm 0.21 \mathrm{~mL} / \mathrm{min}(\mathrm{P}=0.0044)$ for the distal, choke and proximal regions, respectively. Although there was a statistically significant difference for the blood flow in the experimental versus the control muscle, a statistically significant decrease was only found in blood flow from baseline to ligation for the distal region and a statistically significant increase was found in blood flow in the proximal region of the experimental muscle $(\mathrm{P}=0.004$ and $\mathrm{P}=0.005$, respectively) (Table 2 ).

At 15 min postligation, there was no statistically significant change in the blood flow in the distal, choke and proximal regions of the experimental muscle relative to the blood flow at ligation $(\mathrm{P}=0.523, \mathrm{P}=0.128$ and $\mathrm{P}=0.187$, respectively). Relative to the control muscle at this time point, blood flow was lower in the distal and choke regions and higher in the proximal region; however, this difference was only statistically significant for the choke and proximal regions $(\mathrm{P}=0.1206, \mathrm{P}=0.0361$ and $\mathrm{P}=0.0374$ for distal, choke and proximal, respectively).

At 60 min postligation, there was no statistically significant change in the blood flow in the distal, choke and proximal regions of the experimental muscle relative to the blood flow at ligation, or relative to blood flow at 15 min postligation (Table 2). Furthermore, for each anatomical region, there was no statistically significant difference in blood flow between the experimental and control muscle (Table 3). The blood flow in the experimental muscle regions were $0.56 \pm 0.19 \mathrm{~mL} / \mathrm{min}$, $0.72 \pm 0.79 \mathrm{~mL} / \mathrm{min}$ and $1.34 \pm 0.76 \mathrm{~mL} / \mathrm{min}$ for distal, choke and 
TABLE 3

$t$ test for experimental versus control blood flow in each anatomical zone $(\alpha=0.05)$

\begin{tabular}{lccc}
\hline Time & Distal & Choke & Proximal \\
\hline Baseline & 0.8888 & $0.0417^{*}$ & 0.1856 \\
Ligation & $0.0273^{*}$ & $0.0021^{*}$ & $0.0044^{*}$ \\
$15 \mathrm{~min}$ & 0.1206 & $0.0361^{*}$ & $0.0374^{*}$ \\
$60 \mathrm{~min}$ & 0.2835 & 0.1619 & 0.1226 \\
$90 \mathrm{~min}$ & $\mathrm{n} / \mathrm{a}$ & $\mathrm{n} / \mathrm{a}$ & $\mathrm{n} / \mathrm{a}$ \\
\hline
\end{tabular}

${ }^{*} P<0.05 . n / a$ Not applicable

proximal, respectively. The blood flow in the control muscle regions were $1.36 \pm 5.04 \mathrm{~mL} / \mathrm{min}, 1.00 \pm 0.16 \mathrm{~mL} / \mathrm{min}$ and $0.86 \pm 1.96 \mathrm{~mL} / \mathrm{min}$ for distal, choke and proximal, respectively (Table 4).

At 90 min postligation, the blood flow for each anatomical zone of both the experimental and control muscles remained constant (Table 4). However, because only one experiment measured blood flow at this time point, no averaging or statistical analysis was performed. The blood flow in the experimental muscle was $0.41 \mathrm{~mL} / \mathrm{min}, 0.73 \mathrm{~mL} /$ min and $1.43 \mathrm{~mL} / \mathrm{min}$ for the distal, choke and proximal regions, respectively. The blood flow in the control muscle was $1.05 \mathrm{~mL} / \mathrm{min}$, $1.30 \mathrm{~mL} / \mathrm{min}$ and $0.83 \mathrm{~mL} / \mathrm{min}$ for the distal, choke and proximal regions, respectively.

The average blood flow rates from all experiments was plotted. Graphing the average blood flow from all five experiments for each anatomical region as a function of time illustrates the observed changes. Furthermore, the following key trends for the ligated experimental muscle shown in red can be seen: blood flow decreased in the distal region, increased in the proximal region and only slightly deviated in the choke zone (Figure 2). Blood flow changes in the control muscle, shown in blue, are also observed wherein the blood flow remained constant from baseline to the time of ligation and remained fairly constant thereafter.

Method validation: A calibration curve was determined for each fluorescent microsphere, which shows fluorescent intensity increasing linearly with increasing concentration (Figure 3). Analysis of sample spikes showed that the muscle tissue and blood matrices did attenuate with the amount of observed fluorescence (Figure 3). Overall, the actual intensity of each spike was lower than the theoretical intensity values (spike percent recovery $<100 \%$ ). The spike recoveries in muscle tissue were $75.3 \pm 5.4 \%, 48.6 \pm 9.3 \%, 69.5 \pm 9.1 \%$ and $60.2 \pm 4.7 \%$ for the yellow-green, orange, crimson and red fluorescent microspheres, respectively. In blood, spike recoveries were calculated before the experiment as $78.6 \pm 7.8 \%, 44.9 \pm 5.6 \%, 52.4 \pm 7.2 \%$ and $65.0 \pm 0.5 \%$ for the yellowgreen, orange, crimson and red fluorescent microspheres, respectively. Spike recoveries in blood after the experiment were $59.1 \pm 6.9 \%$, $55.1 \pm 5.6 \%, 54.0 \pm 2.6 \%$ and $78.0 \pm 5.3 \%$ for the yellow-green, orange, crimson and red fluorescent microspheres, respectively.

\section{DISCUSSION}

Our research goal was to determine the acute role of the choke vessels in muscle flap surgery. Toward this aim, we sought to learn how choke vessels dilate in response to ligation; and to determine how the changes in blood flow from one anatomical zone affect changes in adjacent anatomical regions. By measuring blood flow changes in three anatomical regions (distal, choke and proximal) using radioactive or fluorescent microspheres, we were able to successfully study the blood flow changes across the muscle flap and the extent of choke vessel dilation in the minutes (acute phase) following ligation of the DIEA of a swine rectus abdominis flap.

Before ligation, we measured the blood flow in each region for both the experimental and control muscles. We found that there was no statistically significant difference in blood flow for both the distal and proximal zone. However, we did find that the blood flow in the choke region of the experimental muscle was statistically less than that in the choke region of the control muscle $(\mathrm{P}=0.0417)$. Although this indicates that before ligation the experimental and control choke zones were not equivalent at the 95\% confidence level, we inferred that if the choke vessels did dilate at the time of ligation, the difference in blood flow between the experimental and control muscle would be of a far greater magnitude.

Ligation of the DIEA resulted in a statistically significant decrease in blood flow of the experimental muscle relative to the control muscle. However, only a statistically significant decrease in the blood flow was observed for the distal region and a statistically significant increase in blood flow was observed in the proximal region from baseline to the time of ligation as a result of increased blood supply from the superior epigastric artery. There was no statistically significant change in blood flow in the choke zone from baseline to ligation, and the blood flow in the choke zone of the experimental muscle remained statistically significantly less in the experimental muscle than in the control muscle. These results indicate that at ligation, the choke vessels do not dilate to allow for the increased blood flow in the proximal region to affect the ligated distal region. These results are in agreement with one of the factors proposed for the mechanism of choke vessel dilation by Dhar and Taylor (5) - the increased blood flow or physical pressure on one side of the choke vessels (in our case the proximal region) - however, there is a time delay for this to occur and our results indicate that in the period immediately following ligation, the choke vessels have not dilated significantly to affect blood flow in the adjacent arterial regions $(5,6)$.

At 15 min postligation, similar trends were noted. There was no statistically significant change in blood flow in the experimental muscle at 15 min compared with the change observed at the time of ligation, and blood flow in the distal region remained statistically significantly lower in the experimental muscle as compared with the control muscle. Although blood flow did increase in the choke zone of the experimental muscle as compared with the time of ligation, this change was not statistically significant and the blood flow remained statistically significantly less in the experimental choke region than in the control choke region. These results indicate that because the blood flow did not statistically change in the distal region, the choke vessels had not yet dilated sufficiently to invoke a measureable change.

Continued blood flow measurements were taken at $60 \mathrm{~min}$ and 90 min postligation. Again, there was no statistically significant change in blood flow at this time point relative to the blood flow measurements at ligation. However, while the blood flow in the proximal region was statistically significantly greater in the experimental muscle at ligation and $15 \mathrm{~min}$ postligation, this difference was no longer seen

\section{TABLE 4}

Blood flow ( $\mathrm{mL} / \mathrm{min})$ in tissue compared with whole muscle blood flow over time in the distal, choke and proximal regions of the flaps

\begin{tabular}{|c|c|c|c|c|c|c|}
\hline \multirow[b]{2}{*}{ Time } & \multicolumn{2}{|c|}{ Distal } & \multicolumn{2}{|c|}{ Choke } & \multicolumn{2}{|c|}{ Proximal } \\
\hline & Experimental & Control & Experimental & Control & Experimental & Control \\
\hline Baseline & $1.16 \pm 0.54$ & $1.12 \pm 0.55$ & $0.89 \pm 0.17$ & $1.07 \pm 0.31$ & $1.04 \pm 0.13$ & $0.90 \pm 0.28$ \\
\hline Ligation & $0.49 \pm 0.16$ & $1.19 \pm 0.57$ & $0.80 \pm 0.09$ & $1.07 \pm 0.15$ & $1.33 \pm 0.05$ & $0.87 \pm 0.21$ \\
\hline $15 \mathrm{~min}$ & $0.58 \pm 0.46$ & $1.21 \pm 0.59$ & $0.90 \pm 0.16$ & $1.05 \pm 0.19$ & $1.23 \pm 0.23$ & $0.87 \pm 0.19$ \\
\hline $60 \mathrm{~min}$ & $0.56 \pm 0.19$ & $1.36 \pm 5.04$ & $0.72 \pm 0.79$ & $1.00 \pm 0.16$ & $1.34 \pm 0.76$ & $0.86 \pm 1.96$ \\
\hline $90 \min ^{*}$ & 0.41 & 1.05 & 0.73 & 1.30 & 1.43 & 0.83 \\
\hline
\end{tabular}

*Only one experiment measured blood flow at $90 \mathrm{~min} . \pm$ values were obtained at the $95 \% \mathrm{Cl}$ 


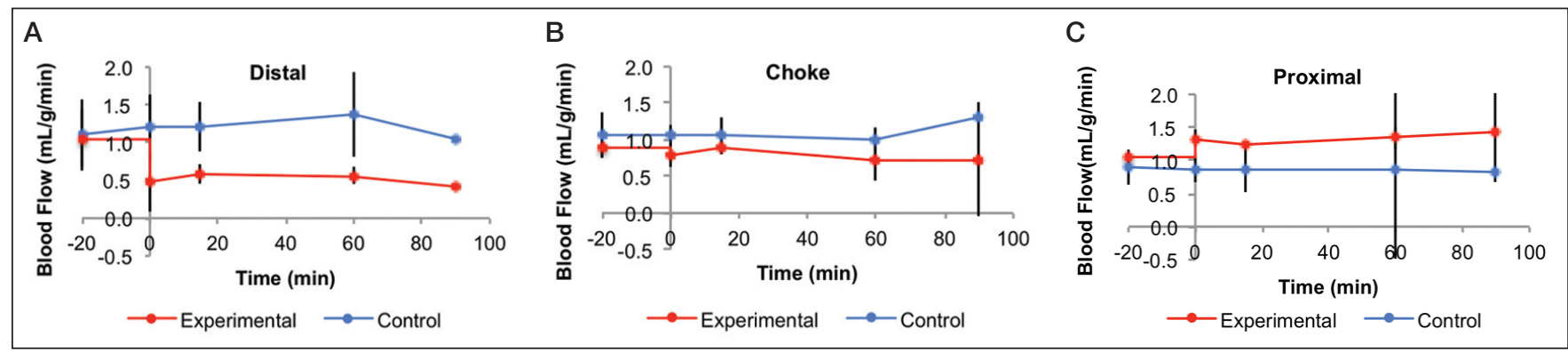

Figure 2) Relative blood flow in experimental and control muscle. A Distal zone; B Choke zone; C Proximal zone; $(-20$ min = baseline; 0 min = ligation)

at $60 \mathrm{~min}$. Furthermore, there was no longer a statistically difference in the blood flow in the choke region between the experimental and control muscle. However, this was not due to an increased blood flow in the experimental choke region, but rather a decrease in blood flow in the choke region of the control muscle. There were no differences in blood flow at 90 min postligation, although statistical analysis was not performed because only one experiment measured blood flow at this time point.

Taking all of the results at each time point together, it is clear that the blood flow in the distal region sharply decreases following ligation and remains relatively constant thereafter. The blood flow in the choke region did not statistically significantly change from baseline to 60 min postligation, and blood flow in the proximal region statistically significantly increased at ligation and remained relatively constant thereafter. This pattern indicates that the choke vessels do not dilate in the acute time following ligation.

While we do not disagree that blood flow may increase to the ligated region after 21 days as Bond et al (4) found for their study of the same muscle in a pig model, their study looked at the entire ligated muscle as compared with the control (4). Although Bond et al showed that the blood flow in the entire muscle decreased, we have now shown in the acute time that the ligated arterial region will decrease in blood flow, and the adjacent arterial region separated by choke vessels will have an increase in blood flow.

While the long-term study of blood flow in ligated muscles is interesting from a theoretical perspective, as plastic surgeons, it is the blood flow in the acute time period that is key for flap viability. The knowledge gained from our study, showing that the choke vessels will not significantly dilate immediately following ligation, has implications for muscle flap surgery.

In a study by Kurita et al (9) in 2010, the duration of ischemia on muscle flap viability was found to not have an influential effect, and that preoperative arterial blood flow and flap volume were the most influential factors for successful flap transfers. Our findings support these observations in that, because the choke vessels do not dilate to give a significant change in blood flow, the duration of ischemia should not be influential. Furthermore, their findings of greater preoperative arterial blood flow and flap volume as the most influential factors for flap transfers indicate that it is the initial state of a muscle flap rather than how the blood flow in a flap changes via dilation or lack of dilation of the choke vessels that is crucial. Larger flaps, which were shown previously to have fewer choke vessels $(2,8)$ should have improved graft patency based on our findings, and this trend is further supported by the clinical observation for larger flap volumes having improved flap viability (9).

Our findings have a clinical implications in that we have contributed to the basic understanding of muscle flap physiology, which will improve flap selection and application in patient care. Flap selection should be based on the immediate viability of the tissue and not dependent on the acute changes in choke zone physiology.

\section{Limitations}

Analysis of the sample spikes to examine matrix effects on fluorescence intensity showed that both blood and muscle tissue attenuated the fluorescence signal for all microspheres. By normalizing the blood flow in a

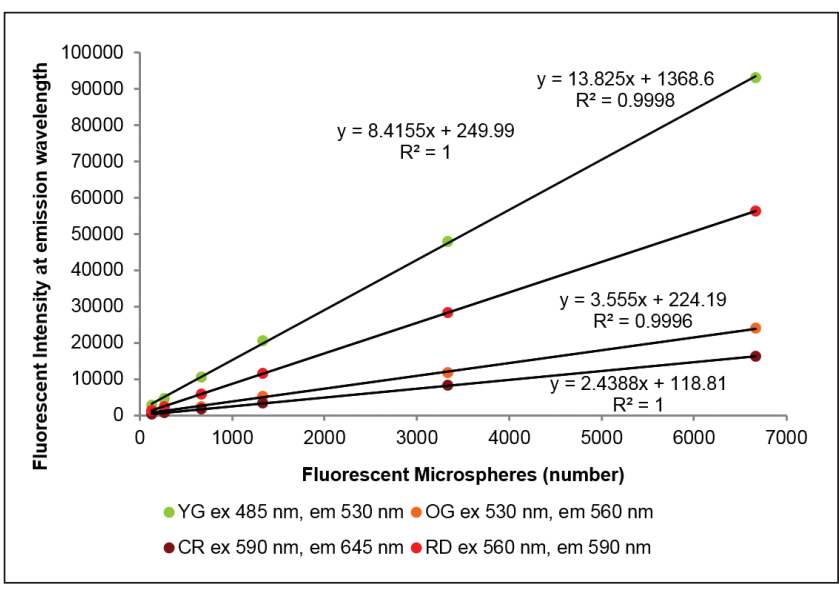

Figure 3) Calibration curve for fluorescent intensity relative to number of microspheres. CR Crimson; em Emission; ex Excitation; OG Orange; RD Red; YG Yellow-green

region against the whole muscle at each time point (same microsphere), we were able to account for this error because each measurement was attenuated by the same amount. Therefore, even though there was systematic error that decreased the accuracy of our results, the precision of our results was not affected and the trends observed were conclusive.

\section{CONCLUSION}

No statistically significant difference in blood flow was detected in the choke zone, establishing that the choke vessels did not dilate enough to affect blood flow up to $90 \mathrm{~min}$ following ligation. Previous literature has shown flap viability is dependent on the amount of vascular resistance and decreases by longer ischemia time. Taken together, these deductions and our own results strongly suggest that the presence of a choke zone in a muscle - and not a dilation of the choke vessel - determine muscle flap viability in the first 90 min following ligation of a pedicle in a type III muscle.

DISCLOSURES: The authors have no financial disclosures or conflicts of interest to declare.

ACKNOWLEDGEMENTS: Anesthesia and preparation for surgery were completed by the animal care staff of the Jack Bell Research Centre, Vancouver, British Columbia. The authors gratefully acknowledge the University of British Columbia Summer Student Research Program for supporting their summer research student, as well as the Vancouver General Hospital Foundation - Allen Estate and University of British Columbia Division of Plastic Surgery for funding our project. They also thank the Division of Plastic Surgery for coordinating this research study and, finally, acknowledge Dr Raman Mahabir, Dr Peter Lennox, Dr Erin Brown, Dr Nick Carr and Dr Nicole Barre for their input and suggestions. 


\section{REFERENCES}

1. Grabb WC, Smith JW. Plastic Surgery, 3rd edn. Boston: Little, Brown, 1979:1.

2. Daniel RK, Williams HB. The free transfer of skin flaps by microvascular anastomoses: An experimental study and a reappraisal. Plast Reconstr Surg 1973;52:16-31.

3. Mathes S, Nahai F. Classification of the vascular anatomy of muscles: Experimental and clinical correlation. Plast Reconstr Surg 1981;67:177-87.

4. Bond S, Ferder M, Grossman L, Strauch B. The effect of epigastric vessel ligation on the vascular territories of the pig rectus muscle. Plast Reconstr Surg 1996;97:616-20.

5. Dhar SC, Taylor GI. The delay phenomenon: The story unfolds. Plast Reconstr Surg 1999;104:2079-91.

6. Cheng XW, Kuzuya M, Kim W, et al. Exercise training stimulates ischemia-induced neovascularization via phosphatidylinositol 3 -kinase/akt-dependent hypoxia-induced factor-1 $\alpha$ reactivation in mice of advanced age. Circulation 2010;122:707-16.

7. Chao HY. Pig muscle flap vascular resistance (unpublished Master's thesis). University of British Columbia, Vancouver; 1998.

8. Mahabir RC, Williamson JS, Carr NJ, Courtemanche DJ. Vascular resistance in human muscle flaps. Ann Plast Surg 2001;47:148-52.

9. Kurita MA, Takushima AA, Shiraishi TA, Okazaki MA, Ozaki MA, Harii KA. Alteration of arterial blood flow after free muscle transfer. Ann Plast Surg 2010;64:477-81.
10. Chang EI, Chang EI, Soto-Miranda MA, et al. Comprehensive evaluation of risk factors and management of impending flap loss in 2138 breast free flaps. Ann Plast Surg 2014 (Epub ahead of print).

11. Guba AJ. Arteriovenous shunting in the pig. Plast Reconstr Surg 1988;63:323-7.

12. Boyd JB, Taylor GI, Corlett R. The vascular territories of the superior epigastric and the deep inferior epigastric systems. Plast Reconstr Surg 1984;73:1-16.

13. Heymann MA, Payne BD, Hoffman JI, Rudolph AM. Blood flow measurements with radionuclide labeled particles. Prog Cardiovasc Dis 1977;20:55-79.

14. Tan WA, Riggs KW, Thies RL, Rurak DW. Use of an automated fluorescent microsphere method to measure regional blood flow in the fetal lamb. Can J Physiol Pharmacol 1997;75:959-68.

15. Hjortdal VE, Hansen ES, Henriksen TB, Kjolseth D, Soballe K, Djurhuus JC. The microcirculation of myocutaneous island flaps in pigs studied with radioactive blood volume tracers and microspheres of different sizes. Plast Reconstr Surg 1992;89:116-22.

16. Chien GL, Anselone CG, Davies RF, Van Winkle DM. Fluorescent vs. radioactive microsphere measurement of regional myocardial blood flow. Cardio Res 1995;30:405-12.

17. Rurak DW, Richardson BS, Patrick JE, Carmichael L, Homan J. Oxygen consumption in the fetal lamb during sustained hypoxemia with progressive acidemia. Am J Physiol 1990;258(5 27-5):R1108-15.

18. Molecular Probes: Product Information Sheet. May 16, 1997. 